\title{
Occurrence of organochlorine pesticides in the environmental matrices from King George Island, west Antarctica
}

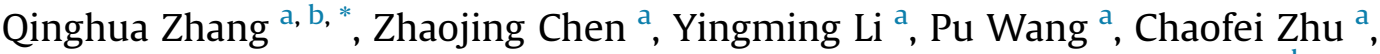 \\ Guanjun Gao a , Ke Xiao a , Huizhong Sun ${ }^{a}$, Shucheng Zheng ${ }^{a}$, Yong Liang ${ }^{b, c}$, \\ Guibin Jiang a \\ a State Key Laboratory of Environmental Chemistry and Ecotoxicology, Research Center for Eco-Environmental Sciences, Chinese Academy of Sciences, \\ Beijing 100085, China \\ b Institute of Environment and Health, Jianghan University, Wuhan 430056, China \\ ${ }^{c}$ School of Medicine, Jianghan University, Wuhan 430056, China
}

\section{A R T I C L E I N F O}

\section{Article history:}

Received 17 April 2015

Received in revised form

16 June 2015

Accepted 21 June 2015

Available online 8 July 2015

\section{Keywords:}

Organochlorine pesticides

Antarctica

Vegetation

Soil

HRGC/HRMS

\begin{abstract}
A B S T R A C T
Antarctica is considered as a final sink of many persistent organic pollutants (POPs). This work aims to investigate the levels, distributions and potential sources of organochlorine pesticides (OCPs) with HRGC/ HRMS technique. Twenty-three OCPs were measured in various environmental matrices from King George Island, west Antarctica. The total concentrations ( $\left.\Sigma_{23} \mathrm{OCPs}\right)$ were at quite low levels, ranging 93.6 $-1260 \mathrm{pg} \mathrm{g}^{-1}$ dry weight (dw) in soil and sediment, 223-1053 $\mathrm{pg} \mathrm{g}^{-1} \mathrm{dw}$ in moss and 373-812 $\mathrm{pg} \mathrm{g}^{-1}$ $\mathrm{dw}$ in lichen. Hexachlorobenzene (HCB), dichloro-diphenyl-trichloroethane (DDT) and its metabolites (especially $p, p^{\prime}$-DDE) and hexachlorocyclohexanes $(\mathrm{HCHs})$ were the main contaminants in all samples. Lower $\alpha-\mathrm{HCH} / \gamma-\mathrm{HCH}$ and higher $p, p^{\prime}$-DDE $/ p, p^{\prime}$-DDT ratios compared with the technical products indicated long-range atmospheric transport (LRAT) of recent lindane and aged technical DDT. Significant dependence of many OCPs concentrations on total organic carbon (TOC) was observed. Apart from LRAT, local biotic activities could also contribute and influence the spatial distribution of the contaminants.
\end{abstract}

() 2015 Elsevier Ltd. All rights reserved.

\section{Introduction}

The occurrence of persistent organic pollutants (POPs) in Antarctica, which is the most isolated continent on Earth, has been recognized as a research priority (Nash, 2011). These compounds with high toxicity, high persistence and bioaccumulation can disperse widely into the environment after released and be transported over long distance from source to colder areas including the Polar Regions (Wania and MacKay, 1996). Therefore, Antarctica is considered to be a final sink of POPs due to the combination of its environmental conditions and the physicochemical properties of the compounds themselves.

Organochlorine pesticides (OCPs) are listed as typical POPs in the Stockholm Convention, which were once widely produced and

\footnotetext{
* Corresponding author. State Key Laboratory of Environmental Chemistry and Ecotoxicology, Research Center for Eco-Environmental Sciences, Chinese Academy of Sciences, Beijing 100085, China.

E-mail address: qhzhang@rcees.ac.cn (Q. Zhang).
}

used globally with a long history. Detection of OCPs (dichlorodiphenyl-trichloroethane (DDT), hexachlorocyclohexane $(\mathrm{HCH})$, heptachlor epoxide and dieldrin) from Antarctic wildlife was reported in 1960s for the first time (Sladen et al., 1966; Tatton and Ruzicka, 1967), and since 1990 there was a restriction and reduction of the global production and usage of nine OCPs listed in "Dirty Dozen" (UNEP, 2001). The primary sources of OCPs such as HCHs and hexachlorobenzene ( $\mathrm{HCB}$ ) have been reduced consequently during the last decades (Breivik et al., 2004). However, they are still found ubiquitously in almost all the environmental matrices such as air, water, snow, soil and biota in Antarctica. For instance, Kang et al. (2012) detected $\alpha-\mathrm{HCH}, \gamma-\mathrm{HCH}$ and HCB with concentrations of $17.5-83.2,33-137$ and n.d. $-182 \mathrm{pg} \mathrm{L}^{-1}$, respectively, in snow samples collected from the coast of east Antarctica. GalbánMalagón et al. (2013a) reported that levels of HCHs (sum of $\alpha-, \beta$ and $\gamma-\mathrm{HCH}$ ) and HCB in seawater samples from west Antarctica in 2008 and 2009 were $1.2-12.3 \mathrm{pg} \mathrm{L}^{-1}$ and $0.41-0.98 \mathrm{pg} \mathrm{L}^{-1}$, respectively. In the meantime, they investigated HCHs and HCB in the atmosphere from Antarctic Peninsula, and the gas phase concentrations of $\alpha-\mathrm{HCH}, \gamma-\mathrm{HCH}$ and $\mathrm{HCB}$ were $0.04-5.8,0.07-7.1$ and 
2.2-49.7 $\mathrm{pg} \mathrm{m}^{-3}$, respectively (Galbán-Malagón et al., 2013b). Cold condensation and global fractionation during the long-range atmospheric transport (LRAT) were proposed as the main mechanism by which POPs ultimately reach the Polar Regions (Wania and MacKay, 1996). Apart from the LRAT, possible local impact (e.g., biotic activities) may also contribute to the environmental pollution in Antarctica (Evenset et al., 2007; Roosens et al., 2007).

Although the investigations of OCPs in Antarctic soil have been conducted previously at several sites, like the east Antarctic coast (Negoita et al., 2003), Victoria Land (Borghini et al., 2005), James Ross Island (Klánová et al., 2008) and Deception and Livingstone Islands (Cabrerizo et al., 2012), there is a limitation of data on HCB, $\mathrm{HCH}(\alpha-$ and $\gamma-\mathrm{HCH})$, DDT and dichlorodiphenyldichloroethylene (DDE) due to the limit of detection capability of gas chromatography (GC) combined with electron capture detector (ECD) or low resolution mass spectrometry (LRMS) which are commonly employed in these studies. Detailed information regarding OCPs in Antarctic soil and terrestrial vegetation is still scarce (Cabrerizo et al., 2012). High resolution gas chromatography coupled with high resolution mass spectrometry (HRGC/HRMS) can provide more reliable results for POPs at trace levels compared with GC/ LRMS (Kang et al., 2012). The method detection limits (MDLs) for OCPs using HRGC/HRMS are reported at relatively low levels (0.3-2.0 $\mathrm{pg} \mathrm{g}^{-1}$ in solid) (US EPA, 2007), which is lower than those by GC/LRMS method (US EPA, 1998). However, limited studies on OCPs in Antarctica were conducted with HRGC/HRMS technique. In this work, HRGC/HRMS was therefore applied for analyzing twenty-three OCPs in various environmental samples from west Antarctica. The objective was to: (1) investigate the levels and distribution patterns of OCPs in this pristine area; (2) assess the potential sources in this region based on the abundant data. To our best knowledge, this is one of the very few studies analyzing so many OCP compounds in Antarctic areas.

\section{Materials and methods}

\subsection{Reagents and materials}

Target OCPs were: HCB, $\alpha-, \beta-, \gamma$ - and $\delta$-HCH, $o, p^{\prime}$ - and $p, p^{\prime}$-DDT, $o, p^{\prime}$ - and $p, p^{\prime}$-DDE, $o, p^{\prime}$ - and $p, p^{\prime}$-dichlorodiphenyldichloroethane (DDD), trans-chlordane (TC), cis-chlordane (CC), oxy-chlordane (OxC), heptachlor (HEPT), cis- and trans-heptachlor epoxide (HE), trans-nonachlor (TN), cis-nonachlor $(\mathrm{CN})$, aldrin, dieldrin, endrin and mirex. All ${ }^{13} \mathrm{C}$-labeled standards of OCPs including surrogate standards (LCS, ES-5349), injection standards (IS, EC-5350) and calibration solutions (CS1-CS6, ES-5348) were purchased from Cambridge Isotope Laboratories (Andover, MA, USA). Pesticidegrade dichloromethane (DCM) and $n$-hexane, and HPLC-grade acetonitrile from J.T. Baker Company Inc. (Fairfield, OH, USA), nonane and alkaline alumina from Sigma (St. Louis, USA), $\mathrm{C}_{18}$ reversed-phase Solid Phase Extraction (SPE) cartridges (LC-18 SPE, $1 \mathrm{~g}, 6 \mathrm{~mL}$ ) from Supelco Inc. (Bellefonte, PA, USA), silica gel 60 (0.063-0.100 mm particle diameter) from Merck (Darmstadt, Germany) and guaranteed grade anhydrous sodium sulfate from the domestic market were used for the entire analysis. Prior to use, silica gel, alkaline alumina and anhydrous sodium sulfate were baked at $550{ }^{\circ} \mathrm{C}$ for $12 \mathrm{~h}, 600{ }^{\circ} \mathrm{C}$ for $24 \mathrm{~h}$ and $660{ }^{\circ} \mathrm{C}$ for $6 \mathrm{~h}$, respectively.

\subsection{Sample collection}

Natural soil ( $\mathrm{n}=7)$, dropping-amended soil $(\mathrm{n}=3)$, sediment $(\mathrm{n}=1$ ), moss (Sanionia uncinata, $\mathrm{n}=7$ ) and lichen (Usnea aurantiacoatra, $\mathrm{n}=6$ ) samples were collected from Fildes Peninsula at King George Island, west Antarctica and the neighboring Ardley
Island. Many international research stations (including Chinese Great Wall Station, Chilean Frei Station and Russian Bellingshausen Station, etc.) are located in Fildes Peninsula, and Ardley Island is an important settlement for the penguins and migrating birds. Nine sampling sites scattered in the vicinity of Chinese Great Wall Station $\left(62^{\circ} 12^{\prime} 59^{\prime \prime} \mathrm{S}, 58^{\circ} 57^{\prime} 52^{\prime \prime} \mathrm{W}\right.$ ) (Fig. 1) and sample details are listed in Table S1 in the Supporting information. Field sampling was conducted in the austral summer of December 11th 2009-January 17th 2010, during the 26th Chinese Scientific Research Expedition to Antarctica. All the samples were sealed in clean plastic bags and transported to the laboratory in Beijing, China and stored frozen $\left(-20^{\circ} \mathrm{C}\right)$ until analysis. A detail description of sampling was presented elsewhere (Wang et al., 2012).

\subsection{Sample extraction and cleanup}

Prior to extraction, the samples were freeze-dried and homogenized, and soil and sediment were sieved through 16-mesh sieve. The procedures of sample extraction and cleanup followed the reported method (Chen et al., 2014). Pesticide extraction was carried out from $5 \mathrm{~g}$ of dried samples using an Accelerated Solvent Extractor (ASE300, Dionex, USA) with a mixture of $n$-hexane: DCM $(1 / 1, \mathrm{v} / \mathrm{v})$ at $150{ }^{\circ} \mathrm{C}$ and $1500 \mathrm{psi}(10.3 \mathrm{MPa})$, after spiking with the ${ }^{13} \mathrm{C}$-labeled standards (OCPs-LCS). Two static cycles of 8 min were applied for complete extraction. Prior to cleanup, activated copper was added to the extracts to remove sulfur. The extracts were then purified by multilayer columns packed with $10 \mathrm{~g}$ of silica gel, $5 \mathrm{~g}$ of alumina (deactivated with $3 \% \mathrm{H}_{2} \mathrm{O}$ ) and $5 \mathrm{~g}$ of anhydrous sodium sulfate from the bottom up. The column was preconditioned with $60 \mathrm{~mL} n$-hexane: DCM $(1 / 1, \mathrm{v} / \mathrm{v})$ and eluted with $100 \mathrm{~mL} n$-hexane: $\operatorname{DCM}(1 / 1, v / v)$. The eluates were evaporated to almost dryness using rotary evaporator, and redissolved in $0.2-0.3 \mathrm{~mL}$ acetonitrile for further cleanup through $C_{18}$ reversed-phase SPE sorbents. The SPE cartridges were pre-rinsed with $6 \mathrm{~mL}$ of acetonitrile and eluted with $12 \mathrm{~mL}$ acetonitrile.

Similar to soil and sediment, $2.0 \mathrm{~g}$ lichen or moss samples were extracted using ASE and purified directly by multilayer silica/ alumina columns and $\mathrm{C}_{18}$ reversed-phase SPE cartridges as described above without sulfur removal. All the eluates were finally concentrated into $20 \mu \mathrm{L}$ nonane in GC-micro-vials by a gentle stream of nitrogen and spiked with the OCPs-IS before instrumental analysis.

\subsection{Instrumental analysis}

Instrumental analysis was performed using an HRGC/HRMS system (DFS, Thermo Fisher, USA) with an electron impact $\left(\mathrm{EI}^{+}\right)$ion source. The HRMS was operated in selected ion recording (SIR) mode at mass resolution $\geq 8000$. The electron emission energy was set to $45 \mathrm{eV}$, and the source temperature was $230^{\circ} \mathrm{C}$. Exactly $1 \mu \mathrm{L}$ solution was injected into HRGC in splitless mode with a $30 \mathrm{~m}$ DB5MS fused silica capillary column (J\&W, Scientific, $0.25 \mu \mathrm{m}$ film thickness, $0.25 \mathrm{~mm}$ i.d.). Helium was the carrier gas with a constant flow of $1.0 \mathrm{~mL} \mathrm{~min}{ }^{-1}$. The GC temperature was programmed as: $60{ }^{\circ} \mathrm{C}$ held for $1.5 \mathrm{~min}$, increased to $140{ }^{\circ} \mathrm{C}$ at $10^{\circ} \mathrm{C} \mathrm{min}-1$, then to $220^{\circ} \mathrm{C}$ at $4{ }^{\circ} \mathrm{C} \mathrm{min}{ }^{-1}$ and $250{ }^{\circ} \mathrm{C}$ at $2^{\circ} \mathrm{C} \mathrm{min}^{-1}$, and finally ramped to $300{ }^{\circ} \mathrm{C}$ at $8{ }^{\circ} \mathrm{C} \mathrm{min}^{-1}$.

\subsection{Quality assurance/quality control ( $Q A / Q C)$}

All the target compounds were analyzed using HRGC/HRMS with an isotope-dilution method. The isotopic ratios between the two main ion pairs were within $\pm 15 \%$ of the theoretical values. OCPs-LCS were utilized for identification and quantification, and OCPs-IS was added for recovery calculation. For every set of 


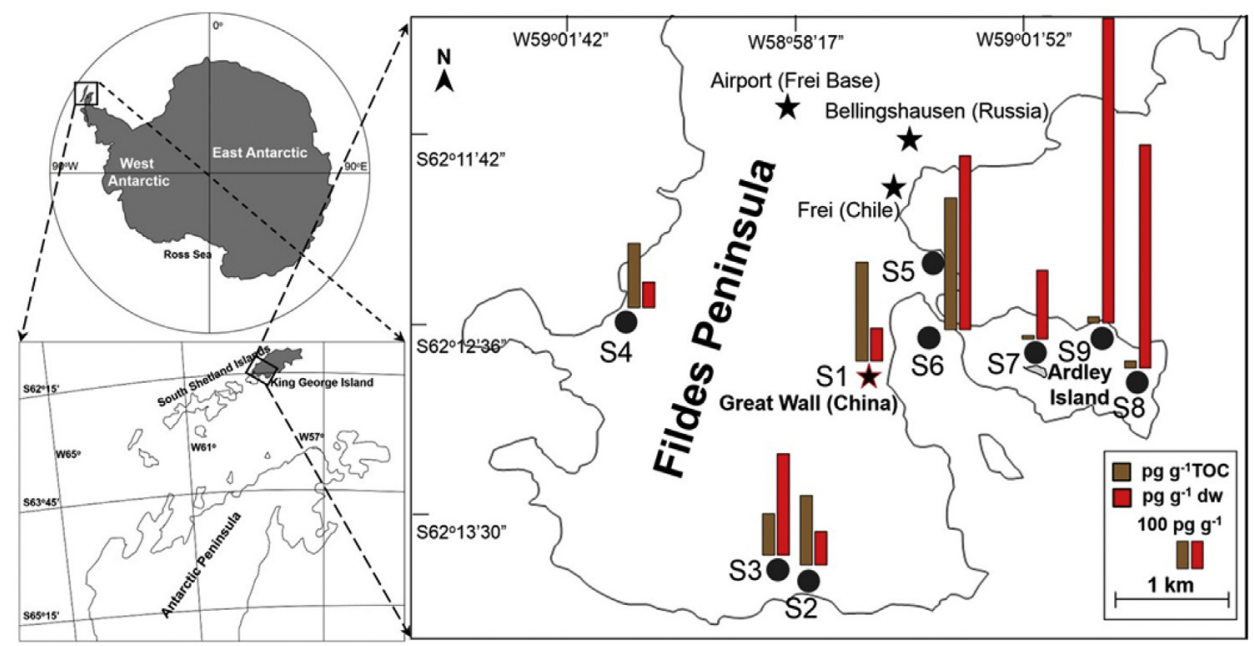

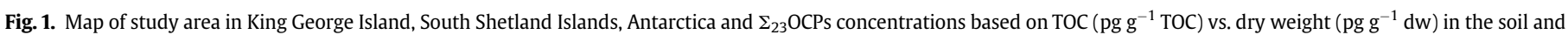
sediment samples.

samples one laboratory blank was processed for quality control. In the laboratory blanks, only $\mathrm{HCB}, \alpha-\mathrm{HCH}$ and $p, p^{\prime}$-DDE were detected at $<1 \%$ to $20 \%$ of levels found in the whole samples, while other OCPs were not detected. The sample recoveries of OCPs-LCS were in the range of $40-100 \%$, which satisfied within the recovery limit of EPA method 1699 (US EPA, 2007). The limit of detection (LOD) was defined as signal-to-noise ratio $(\mathrm{S} / \mathrm{N})=3$ and was calculated for each analyzed sample. In this study, the LODs were in the range of $0.02-8.99,0.19-17.94$ and $0.02-22.71 \mathrm{pg} \mathrm{g}^{-1} \mathrm{dw}$ in soil and sediment, moss and lichen samples, respectively, which were approximately one order of magnitude lower than other reported results in Antarctica (Borghini et al., 2005; Klánová et al., 2008; Negoita et al., 2003; Zhang et al., 2007, 2013) (Table S4).

\section{Results and discussion}

\subsection{OCPs levels and composition in the soil and sediment samples}

Concentration levels of twenty-three OCPs in the environmental matrices from west Antarctica are shown in Fig. 2. Comparisons with other reported results in Antarctic soil and vegetation are presented in Tables 1 and 2. Detailed concentrations (mean, min-max, median, $\mathrm{pg} \mathrm{g}^{-1} \mathrm{dw}$ ) and detection frequencies of OCPs are listed in Table S5. All the OCPs except trans-HE were detected in samples, with HCB, DDTs, HCHs being the most prevalent contaminants and other compounds at less detection frequencies.

Total OCPs concentrations ( $\Sigma_{23} \mathrm{OCPs}$ ) in soil and sediment were in the range of 93.6-1260 $\mathrm{pg} \mathrm{g}^{-1}$ dry weight (dw) with an average $451 \mathrm{pg} \mathrm{g}^{-1} \mathrm{dw}$. HCB was the dominant pollutant in all soil samples with the concentrations of $67.9-532 \mathrm{pg} \mathrm{g}^{-1} \mathrm{dw}$, followed by DDTs (sum of $p, p^{\prime}$-DDT, $o, p^{\prime}$-DDT, $p, p^{\prime}$-DDE, $o, p^{\prime}$-DDE, $p, p^{\prime}$-DDD, and $o, p^{\prime}-$ DDD, $18.8-308 \mathrm{pg} \mathrm{g}^{-1} \mathrm{dw}$ ), HCHs (sum of $\alpha-, \beta-, \gamma-$ and $\delta-\mathrm{HCH}$, $6.25-232 \mathrm{pg} \mathrm{g}^{-1} \mathrm{dw}$ ) and chlordane compounds (CHLs, sum of CC, TC, OxC, CN, TN, HEPT, cis-HE and trans-HE, n.d.-59.7 pg g $^{-1} \mathrm{dw}$ ). OCPs including dieldrin, endrin, mirex and CHLs were detected only in particular soil samples, whereas aldrin was below detection limit. The concentrations of HCB, DDTs, HCHs and their individuals detected in the soil and sediment are consistent with many other results reported previously in west Antarctica. For example, $\mathrm{HCHs}$ (sum of $\alpha-, \beta-\mathrm{HCH}$ ), DDTs (sum of $p, p^{\prime}-\mathrm{DDE}, p, p^{\prime}$-DDT) in background soil and dropping-amended soil samples from King George Island and Adley Island during 2001-2002 were measured by

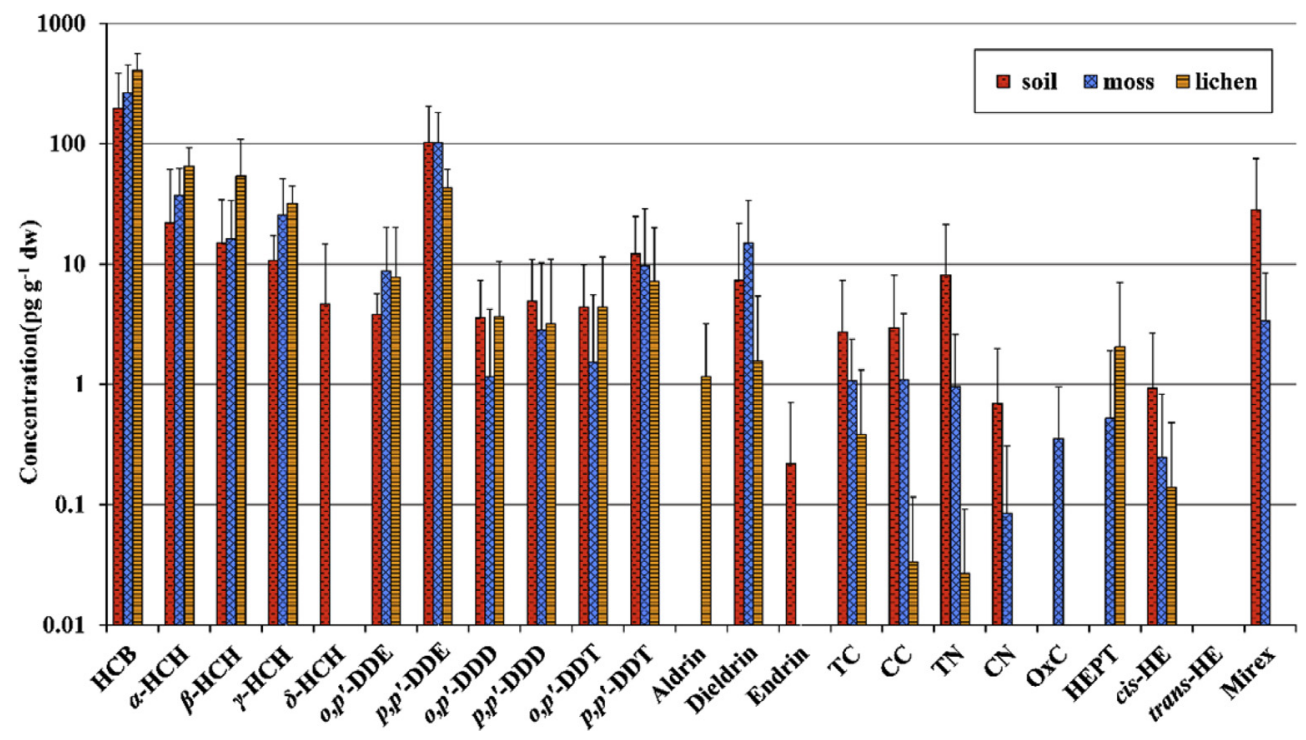

Fig. 2. Concentrations of OCPs in soil, moss and lichen samples. 
Table 1

Comparison of several OCPs levels ( $\mathrm{pg} \mathrm{g}^{-1} \mathrm{dw}$ ) with other studies in the Antarctic soil.

\begin{tabular}{|c|c|c|c|c|c|c|c|c|c|c|c|}
\hline Sample type & Sampling location & Year & $\mathrm{HCB}$ & $\mathrm{HCHs}$ & DDTs & $\alpha-\mathrm{HCH}$ & $\gamma-\mathrm{HCH}$ & $p, p^{\prime}-\mathrm{DDE}$ & $p, p^{\prime}-\mathrm{DDT}$ & TOC (\%) & Ref. \\
\hline Soil & East Antarctic coast & 1998 & $20-25,280$ & $860-43,060^{a}$ & $110-26,460^{\mathrm{b}}$ & $90-2690$ & $710-40,050$ & $30-3190$ & $40-14,890$ & $0.01-4.11$ & $\begin{array}{l}\text { Negoita et al., } \\
2003\end{array}$ \\
\hline Soil & $\begin{array}{l}\text { Victoria Land, } \\
\text { East Antarctica }\end{array}$ & 1999-2000 & $34-170$ & & & $<10-26$ & & $53-86$ & $<5-20$ & & $\begin{array}{l}\text { Borghini et al., } \\
2005\end{array}$ \\
\hline Soil & King George Island & 2001-2002 & & $60-380^{a}$ & $90-190^{c}$ & $170-310$ & $<20-70$ & $90-130$ & $<50-60$ & & $\begin{array}{l}\text { Zhang et al., } \\
2007\end{array}$ \\
\hline $\begin{array}{l}\text { Dropping- } \\
\text { amended soil }\end{array}$ & Adley Island & $2001-2002$ & & $240-390^{\mathrm{a}}$ & $160-650^{c}$ & $200-650$ & $30-110$ & $70-1640$ & $<50-400$ & & $\begin{array}{l}\text { Zhang et al. } \\
2007\end{array}$ \\
\hline Soil & James Ross Island & 2005 & $2410-7750$ & $490-1340^{a}$ & $510-3680^{c}$ & & & & & $0.09-0.34$ & $\begin{array}{l}\text { Klánová et al., } \\
2008\end{array}$ \\
\hline Sediment & James Ross Island & 2005 & $950-4000$ & $140-760^{a}$ & $190-1150^{c}$ & & & & & $0.04-1.71$ & $\begin{array}{l}\text { Klánová et al., } \\
2008\end{array}$ \\
\hline Soil & $\begin{array}{l}\text { Deception and } \\
\text { Livingstone Islands }\end{array}$ & 2008-2009 & n.d. -70 & & & & & n.d. -200 & & $<0.1-1.66$ & $\begin{array}{l}\text { Cabrerizo et al., } \\
2012\end{array}$ \\
\hline Sediment & $\begin{array}{l}\text { West Antarctic } \\
\text { Peninsula }\end{array}$ & 2008 & $2-130$ & & & & & $20 \pm 10$ & & $0.46-1.02$ & $\begin{array}{l}\text { Zhang et al., } \\
2013\end{array}$ \\
\hline Soil & $\begin{array}{l}\text { King George and } \\
\text { Adley Island }\end{array}$ & 2009-2010 & $67.9-108$ & $6.25-31^{\mathrm{a}}$ & $18.8-277^{\mathrm{d}}$ & $5.01-15.2$ & n.d. -11.9 & $10.6-181$ & $4.19-44.8$ & $0.33-20$ & This study \\
\hline $\begin{array}{l}\text { Dropping- } \\
\text { amended soil }\end{array}$ & Adley Island & 2009-2010 & $368-532$ & $40.5-232^{\mathrm{a}}$ & $223-308^{\mathrm{d}}$ & $10.4-131$ & $8.94-24.0$ & $192-272$ & $5.41-7.25$ & $34-55.9$ & This study \\
\hline Sediment & King George Island & 2009-2010 & 57.7 & $3.05^{\mathrm{a}}$ & $577^{\mathrm{d}}$ & 3.05 & n.d. & 38.1 & 313 & 1.32 & This study \\
\hline
\end{tabular}

a Sum of $\alpha-, \beta-, \gamma$ - and $\delta$-HCH.

b Sum of $o, p^{\prime}$-DDT, $o, p^{\prime}$-DDD, $p, p^{\prime}-\mathrm{DDT}, p, p^{\prime}-\mathrm{DDE}, p, p^{\prime}$-DDD.

c Sum of $p, p^{\prime}$-DDT, $p, p^{\prime}$-DDE, $p, p^{\prime}$-DDD.

d Sum of $p, p^{\prime}$-DDT, $p, p^{\prime}-\mathrm{DDE}, p, p^{\prime}-\mathrm{DDD}, o, p^{\prime}$-DDT, $o, p^{\prime}$-DDE and $o, p^{\prime}-\mathrm{DDD}$.

Zhang et al. (2007), with concentrations of 60-380 $\mathrm{pg} \mathrm{g}^{-1} \mathrm{dw}$, 90-190 $\mathrm{pg} \mathrm{g}^{-1} \mathrm{dw}$ and $240-390 \mathrm{pg} \mathrm{g}^{-1} \mathrm{dw}, 160-650 \mathrm{pg} \mathrm{g}^{-1} \mathrm{dw}$, respectively. $\mathrm{HCB}$ and $p, p^{\prime}$-DDE levels in the background soil at Deception and Livingstone Islands during 2008-2009 were determined in the range of n.d. -70 and n.d. -200 pg g $^{-1} \mathrm{dw}$ by Cabrerizo et al. (2012). HCB concentrations in sediments were detected between $2-130 \mathrm{pg} \mathrm{g}^{-1} \mathrm{dw}$ from west Antarctic Peninsula in 2008 by Zhang et al. (2013). However, much higher concentrations of HCB, DDTs and $\mathrm{HCHs}$ in soils around the research stations of east Antarctica (Negoita et al., 2003), and CHLs (sum of OxC, TC, CC, and $\mathrm{TN}, 3-599 \mathrm{pg} \mathrm{g}^{-1} \mathrm{dw}$ ) in soils from penguin colonies of east Antarctic coast (Roosens et al., 2007) have been reported. Higher levels of DDTs than HCHs in most soil and sediment may be attributed to larger amounts of DDT used in agricultural activities than $\mathrm{HCH}$ formulations (Tarcau et al., 2013), and to a less extent due to the differences in physicochemical properties (Table S2) that HCHs have higher biodegradability, lower lipophilicity and lower particle affinity compared with DDTs (Loganathan and Kannan, 1994).

OCPs in the dropping-amended soil had a different distribution profile from the natural soil samples. And higher OCPs levels (up to one order of magnitude) were found in the dropping-amended soil. Concentrations of $\Sigma_{23}$ OCPs were in the range of 93.6-371 $\mathrm{pg} \mathrm{g}^{-1}$ dw (average $176 \mathrm{pg} \mathrm{g}^{-1} \mathrm{dw}$ ) and 148-250 $\mathrm{pg} \mathrm{g}^{-1} \mathrm{dw}\left(188 \mathrm{pg} \mathrm{g}^{-1}\right.$ $\mathrm{dw}$ ) in the natural soil from Fildes Peninsula, King George Island (sampling sites S1-S4) and Ardley Island (sampling sites S7-S9), respectively, whereas they were $968-1260 \mathrm{pg} \mathrm{g}^{-1} \mathrm{dw}\left(1015 \mathrm{pg} \mathrm{g}^{-1}\right.$ $\mathrm{dw}$ ) in the dropping-amended soil from Ardley Island (sampling sites S8-S9). CHLs, dieldrin, endrin and mirex were detected mainly in dropping-amended soil samples. Higher OCPs levels in dropping-amended soil was in agreement with reported result by Zhang et al. (2007). Many studies suggested that biotic focusing of POPs could induce elevated contamination levels and become more significant than abiotic pathways (air or water) on a local scale (Blais et al., 2007; Evenset et al., 2007). Considering that Ardley Island is an important settlement for penguins (a non-migratory species that spends its entire life in the Antarctic) and many migrating birds during the summer, the elevated contamination in soil from Ardley Island could therefore be attributed to the migrating birds activity as well as redistribution and concentration of contaminants by local penguin activity (such as excrement and

Table 2

Comparison of several OCPs levels ( $\mathrm{pg} \mathrm{g}^{-1} \mathrm{dw}$ ) with other studies in the Antarctic vegetation.

\begin{tabular}{|c|c|c|c|c|c|c|c|c|c|c|}
\hline Sample type & Sampling location & Year & $\mathrm{HCB}$ & $\mathrm{HCHs}$ & DDTs & $\alpha-\mathrm{HCH}$ & $\gamma-\mathrm{HCH}$ & $p, p^{\prime}-\mathrm{DDE}$ & $p, p^{\prime}-\mathrm{DDT}$ & Ref. \\
\hline Moss & King George Island & $2009-2010$ & $139-663$ & $21.1-162^{\mathrm{a}}$ & $20.1-324^{\mathrm{b}}$ & $9.48-83.6$ & n.d. -78.7 & $19.9-228$ & n.d. -50.8 & This study \\
\hline Lichen & King George Island & 2009-2011 & $207-632$ & $58.4-293^{\mathrm{a}}$ & $25.5-125^{\mathrm{b}}$ & $26.1-96.9$ & $19.6-52.1$ & $25.5-66.1$ & n.d. -31.6 & This study \\
\hline Moss & $\begin{array}{l}\text { Deception and Livingstone } \\
\text { Islands }\end{array}$ & $2008-2009$ & $21-120$ & & & & & $5-40$ & n.d. -14 & Cabrerizo et al., 2012 \\
\hline Lichen & $\begin{array}{l}\text { Deception and Livingstone } \\
\text { Islands }\end{array}$ & 2008-2009 & $2-310$ & & & & & $3-10$ & n.d. -9 & Cabrerizo et al., 2012 \\
\hline Moss & King George Island & 2004-2005 & $811 \pm 180$ & $1200 \pm 810^{a}$ & $1620 \pm 580^{\mathrm{b}}$ & & & & & Cipro et al., 2011 \\
\hline Lichen & King George Island & $2004-2005$ & $141 \pm 100$ & $205 \pm 80^{\mathrm{a}}$ & $353 \pm 40^{\mathrm{b}}$ & & & & & Cipro et al., 2011 \\
\hline Moss & Antarctic Peninsula & 1985 & $300-680$ & & & $230-1150$ & $400-1700$ & $170-530$ & $250-550$ & Bacci et al., 1986 \\
\hline Lichen & Antarctic Peninsula & 1985 & $300-2160$ & & & $200-800$ & $500-1030$ & $100-600$ & $80-900$ & Bacci et al., 1986 \\
\hline Moss & Victoria Land, East Antarctica & 1999-2000 & $850-1900$ & & & $430-4000$ & $180-1600$ & $1100-7900$ & $540-910$ & Borghini et al., 2005 \\
\hline Lichen & East Antarctic coast & 1998 & 300 & $59,700^{\mathrm{a}}$ & $1880^{c}$ & 3930 & 54,980 & 400 & 710 & Negoita et al., 2003 \\
\hline Moss & Kay Land, East Antarctica & 1988 & $110-790$ & & & $100-270$ & $20-1080$ & $400-900$ & $100-400$ & Focardi et al., 1991 \\
\hline
\end{tabular}

\footnotetext{
a Sum of $\alpha-, \beta-, \gamma$ - and $\delta-\mathrm{HCH}$.

b Sum of $p, p^{\prime}$-DDT, $p, p^{\prime}$-DDE, $p, p^{\prime}$-DDD, $o, p^{\prime}-\mathrm{DDT}, o, p^{\prime}-\mathrm{DDE}$ and $o, p^{\prime}-\mathrm{DDD}$.

c Sum of $o, p^{\prime}$-DDT, $o, p^{\prime}-\mathrm{DDD}, p, p^{\prime}-\mathrm{DDT}, p, p^{\prime}-\mathrm{DDE}, p, p^{\prime}-\mathrm{DDD}$.
} 
carcasses), which has also been explained in other studies on OCPs in the east coast of Antarctica (Negoita et al., 2003; Roosens et al., 2007).

\subsection{OCPs levels and composition in lichen and moss samples}

The overall concentrations of $\Sigma_{23} \mathrm{OCPs}$ in moss and lichen samples ranged between $223-1053 \mathrm{pg} \mathrm{g}^{-1} \mathrm{dw}$ (average $492 \mathrm{pg} \mathrm{g}^{-1} \mathrm{dw}$ ) and $373-812 \mathrm{pg} \mathrm{g}^{-1} \mathrm{dw}\left(635 \mathrm{pg} \mathrm{g}^{-1} \mathrm{dw}\right)$, respectively. Levels of OCPs in mosses followed the same order as described in soils, whereas the order was HCB $>$ HCHs $>$ DDTs $>$ CHLs in lichens. Concentrations of HCB, DDTs, HCHs and CHLs were 266 (139-663), 125 (20.1-324), $79.0(21.1-162)$ and 4.32 (n.d.-15.6) $\mathrm{pg} \mathrm{g}^{-1} \mathrm{dw}$ in mosses and 410 (207-632), 69.3 (25.5-125), 150 (58.4-293) and 2.63 (n.d.-14.6) pg $\mathrm{g}^{-1} \mathrm{dw}$ in lichens, respectively. Mosses (S. uncinata) predominate in moister soil and more sheltered habitats, while lichens ( $U$. aurantiacoatra) predominate in the more arid, exposed rocky habitats (Cipro et al., 2011; Kim et al., 2007). Considering HCB and HCHs are more volatile than DDTs and CHLs, thus, it seems that the different ecology of mosses and lichens made a difference on their concentrations of OCPs. HCB, DDTs, HCHs and their congeners in mosses and lichens in this study are in lower ranges than the values previously reported in east Antarctica (Borghini et al., 2005; Focardi et al., 1991; Negoita et al., 2003) (Table 2). A recent study from the coast of Admiralty Bay, King George Island in the austral summer of 2004-2005 reported that HCB, HCHs and DDTs levels were $141 \pm 100,205 \pm 80$ and $353 \pm 40 \mathrm{pg} \mathrm{g}^{-1} \mathrm{dw}$ in lichens, respectively (Cipro et al., 2011), which were at the same range with the present results. No previous data of CHLs and heptachlor have been found to compare in Antarctic vegetation.

Aldrin and dieldrin are two structurally similar compounds, which were once used as insecticides, and dieldrin could be produced by the epoxidation of aldrin (ATSDR, 2002a). In this study, dieldrin was found at low levels in the range of n.d.-39.3 and n.d. $-9.38 \mathrm{pg} \mathrm{g}^{-1} \mathrm{dw}$ in mosses and lichens, which were still higher than aldrin (undetected in mosses and n.d. $-5.28 \mathrm{pg} \mathrm{g}^{-1} \mathrm{dw}$ lichens). This is consistent with the fact that aldrin and dieldrin evaporate slowly in the air, and aldrin can readily change into dieldrin once it enters either the environment or the body (ATSDR, 2002a). Endrin was not detected in either mosses or lichens, which was a stereoisomer of dieldrin. Mirex, the trade name of which was Dechlorane, was found at low concentrations of n.d. $-8.1 \mathrm{pg} \mathrm{g}^{-1} \mathrm{dw}$ in mosses and undetected in lichens.

\subsection{Profiles and source analysis of OCPS}

\subsection{1. $\mathrm{HCHs}$}

The ratio of $\alpha-/ \gamma-\mathrm{HCH}$ can indicate the possible sources of historical or recent input of $\mathrm{HCHs}$ and transport pathway to the environment (Brubaker and Hites, 1998; Kawano et al., 1988). Past heavily used technical $\mathrm{HCH}$ contains approximately: $\alpha, 60-70 \% ; \beta$, $5-12 \% ; \gamma, 10-15 \%$ and $\delta, 6-10 \%$ isomers with $\alpha-/ \gamma-\mathrm{HCH}$ ratio of $3-7$ (Willett et al., 1998). Pure lindane, containing more than $90 \% \gamma-\mathrm{HCH}$ (the active ingredient of the technical $\mathrm{HCH}$ mixture), replaced technical $\mathrm{HCH}$ and was used as a pesticide in many countries (Walker et al., 1999; Wu et al., 1997). HCH isomers have differential partitioning in the environment since their different physicochemical properties. $\beta-\mathrm{HCH}$ has low volatility and is resistant to hydrolysis and microbial degradation, while $\alpha-\mathrm{HCH}$ and $\gamma-\mathrm{HCH}$ are more volatile, leading to more likely to partition in the air and transport over long distance (Wu et al., 2013). In addition, $\gamma-\mathrm{HCH}$ can be converted to $\alpha-\mathrm{HCH}$ through light or the actions of soil microorganisms (Iwata et al., 1993; Pacyna and Oehme, 1988), thereby causing an increase of $\alpha-/ \gamma-\mathrm{HCH}$ ratio with the distance of transportation and the time of duration (Zhang et al., 2007). In the whole samples of this study, $\alpha$-, $\beta$ - and $\gamma-\mathrm{HCH}$ accounted for $44 \%$, $26 \%$ and $29 \%$ of total $\mathrm{HCHs}$, respectively, whereas $\delta$ - $\mathrm{HCH}$ percentage was only $1 \%$ (Fig. 3). The ratios of $\alpha-/ \gamma-\mathrm{HCH}$ in soils, mosses and lichens were $1.61 \pm 2.06,1.56 \pm 0.41$ and $2.07 \pm 0.55$, respectively, which were lower than the ratio in technical $\mathrm{HCH}$. This is in accordance with the values found in soil and sediment samples from James Ross Island $(\alpha-/ \gamma-\mathrm{HCH}, 0.5)$ (Klánová et al., 2008), vegetation samples from Antarctic Peninsula (0.28-1.09) (Bacci et al., 1986) and atmospheric sample near King Sejong Antarctic station (2.85) (Baek et al., 2011), indicating the combined sources of "old" technical $\mathrm{HCH}$ and "recent" lindane $(\gamma-\mathrm{HCH})$ to Antarctica (Wu et al., 2014). There was no statistically significant correlation between $\alpha-\mathrm{HCH}$ and $\gamma-\mathrm{HCH}(p>0.05)$, confirming that $\alpha-\mathrm{HCH}$ and $\gamma-\mathrm{HCH}$ were originated from different sources. In addition, in an inventory of POPs contamination in the Southern Hemisphere, it was shown that relatively high amounts of pesticides (especially lindane and DDT) were used in Australia and South America (Connell et al., 1999). Concentrations of $\beta$ - $\mathrm{HCH}$ with the range of n.d. -56.8 , n.d. -52.6 and $12.4-144 \mathrm{pg} \mathrm{g}^{-1} \mathrm{dw}$ in soils, mosses and lichens, respectively, were higher than $\alpha-\mathrm{HCH}$ and $\gamma-\mathrm{HCH}$ in several sites. The reason could be the fact that $\beta-\mathrm{HCH}$ is more persistent in the environment, which has been described above.

\subsection{2. $D D T s$}

DDT is a broad spectrum pesticide used widely to control insects on agricultural crops and insects that carry diseases like malaria and typhus, which does not occur naturally in the environment. Although the usage of DDT has been banned in many countries since 1970s, it was still found in some tropical countries to control malaria (Ali et al., 2014). Technical-grade DDT, the grade generally used as an insecticide, was a mixture of active ingredient $p, p^{\prime}$-DDT $(85 \%)$ and inactive $o, p^{\prime}$-DDT (15\%), which may also contain few DDE and DDD (ATSDR, 2002b). There was no commercial use of DDE,
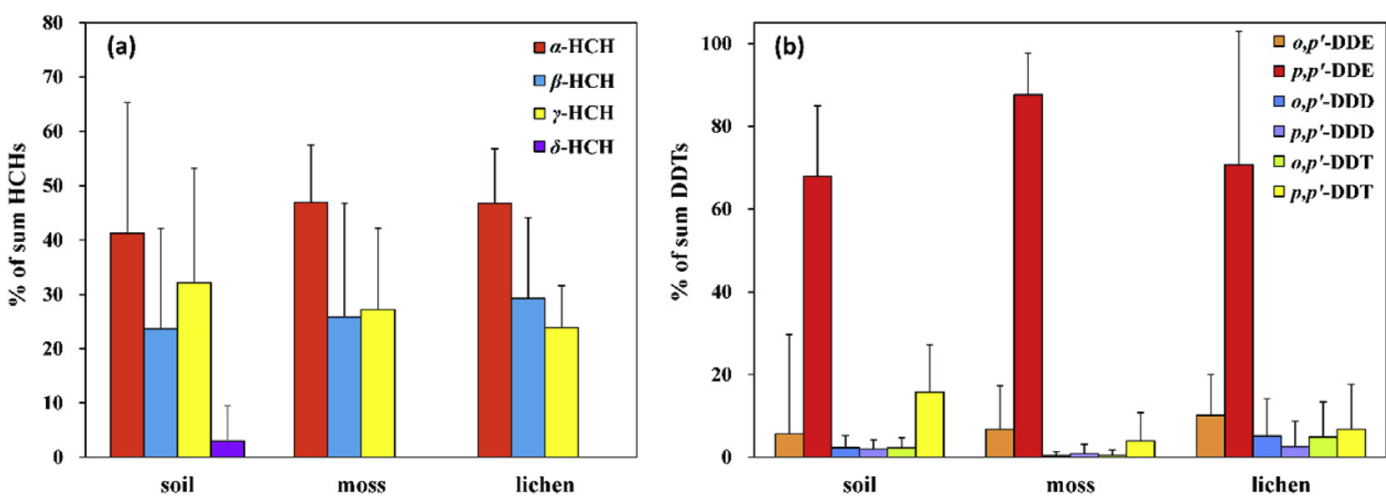

Fig. 3. Composition of HCHs (a) and DDTs (b) in soil, moss and lichen samples. 
whereas $p, p^{\prime}$-DDD was used as an insecticide to a limited extent in the past, and $o, p^{\prime}$-DDD (Mitotane) is used as medical purpose to treat cancer. In general, DDD and DDE enter into the environment mainly as two degradation products of DDT dehydrohalogenation (ATSDR, 2002b).

The ratios of $p, p^{\prime}$-DDE $/ p, p^{\prime}$-DDT have been applied to establish whether the DDT emission occurred recently or in the history (Pozo et al., 2004; Wang et al., 2009). The ratio of $p, p^{\prime}$-DDE/DDT $>1$ indicates old inputs of DDT and $p, p^{\prime}$-DDE/DDT $<1$ indicates fresh inputs (Cabrerizo et al., 2012). In this study, p,p'-DDE (76\%) was the dominant contributor among the total DDTs, followed by $p, p^{\prime}$-DDT, $o, p^{\prime}$-DDE, $o, p^{\prime}$-DDD, $o, p^{\prime}$-DDT and $p, p^{\prime}$-DDD (10\%, 7\%, 2.5\%, $2.5 \%$ and $2 \%$, respectively, Fig. 3). Higher concentrations of $p, p^{\prime}$-DDE than other DDT forms were found in all samples, which is consistent with the fact that $p, p^{\prime}$-DDT is subject to degradation to more stable and toxic metabolites such as $p, p^{\prime}$-DDE in the environment (Cabrerizo et al., 2012). The available values of $p, p^{\prime}$-DDE/p, $p^{\prime}$-DDT (1.5-4.9 in natural soils, 35-39 in dropping-amended soils, 1.4-6.8 in mosses and lichens) were much greater than 1 , suggesting old DDT accumulations in the local area. DDT can biodegrade to DDE under aerobic conditions and to DDD under anaerobic conditions (Hitch and Day, 1992). Therefore, the ratio of DDE/DDD could denote the possible pathway of DDT biodegradation: DDE/DDD $>1$ indicates aerobic degradation is the main factor of DDT loss and ratio <1 indicates anaerobic degradation (Wu et al., 2013). Accordingly, higher ratios of $p, p^{\prime}-\mathrm{DDE} / p, p^{\prime}$-DDD than 1 in most samples (10.2 in natural soils, 22.7-36.6 in dropping-amended soils, 2.4-11.6 in mosses and lichens) confirmed DDT loss mainly by aerobic biodegradation. Furthermore, relatively high detection rates of DDT indicated that a small amount of fresh DDT input may still occurred in this area.

\subsubsection{CHLS}

CHLs are usually expressed as the sum of several of the most abundant and persistent components and metabolites of the technical chlordane. Technical chlordane is a mixture of many related chemicals, primarily composed of TC, CC, TN, and trace amounts of CN, HEPT and OxC (Sovocool et al., 1977). TN is the most bioaccumulative compound among the CHLs. HEPT was also applied as an insecticide during 1940s-1980s (ATSDR, 2007). In this study, TC, CC and TN levels in soils were in the range of 2.73 (n.d.-11.7), 2.94 (n.d.-12.2) and 8.11 (n.d.-31.4) pg g ${ }^{-1}$ dw, respectively, while $\mathrm{CN}$ was 0.69 (n.d.-3.17) $\mathrm{pg} \mathrm{g}^{-1} \mathrm{dw}$, consistent with the composition of technical chlordane (Sovocool et al., 1977). Both HEPT and HE were found at very low levels comparable to CN. The ratios of TC, CC and TN (TC:CC:TN) were 1.00:1.08:2.97 in soils, which were different from those in the original technical mixture (1.26:1.01:0.37) (Kim et al., 2002). Considering the persistency of chlordane components in order of TN $>\mathrm{CC}>\mathrm{TC}$ and the higher Henry's law constant of TN than those of the other two components (Iwata et al., 1993), the ratios obtained in this study suggested the presence of aged technical chlordane in this region.

\subsection{The effect of total organic carbon (TOC) and lipid contents}

The total organic carbon (TOC) and lipid contents of all collected samples were determined elsewhere (Table S1) (Wang et al., 2012). OCP concentrations, TOC and lipid contents were all logtransformed before correlation in order to obtain normal distributed variables according to the Kolmogorov-Smirnov test.

Soil organic matter plays an important role in partitioning and retention of POPs in the soil system (Meijer et al., 2003; Nam et al., 2008). Significant correlations of $\Sigma_{23}$ OCPs concentrations in soil and sediment with TOC were observed, especially for HCB, $\alpha-\mathrm{HCH}$, $\beta$-HCH, $\gamma$-HCH, $p, p^{\prime}$-DDE, HCHs and DDTs $\left(\mathrm{R}^{2}=0.24-0.74 ; p \leq 0.05\right.$, Fig. 4). The linear correlation between OCPs and TOC is consistent with studies in other background areas (Ribes et al., 2002; Sweetman et al., 2005; Yang et al., 2013). However, for mosses and lichens, there was no statistical significance observed between the lipid contents and OCPs concentrations except $p, p^{\prime}$-DDE.

It should be noted that the normalized OCPs concentrations based on TOC showed a reversed spatial distribution compared with those on dry weight (Fig. 1). Higher $\Sigma_{23}$ OCPs concentrations were found in the sites around Fildes Peninsula than in Ardley Island, especially for $\mathrm{HCB}, \mathrm{HCH}$ and DDTs (Fig. S1). The highest concentration of $\Sigma_{23} \mathrm{OCPs}$ and HCB in soil samples was collected in the vicinity of Chinese Great Wall Station (sampling site S1). Higher TOC normalized concentrations around Fildes peninsula might supported the hypothesis of anthropogenic impact on the POPs distribution in Antarctic areas.

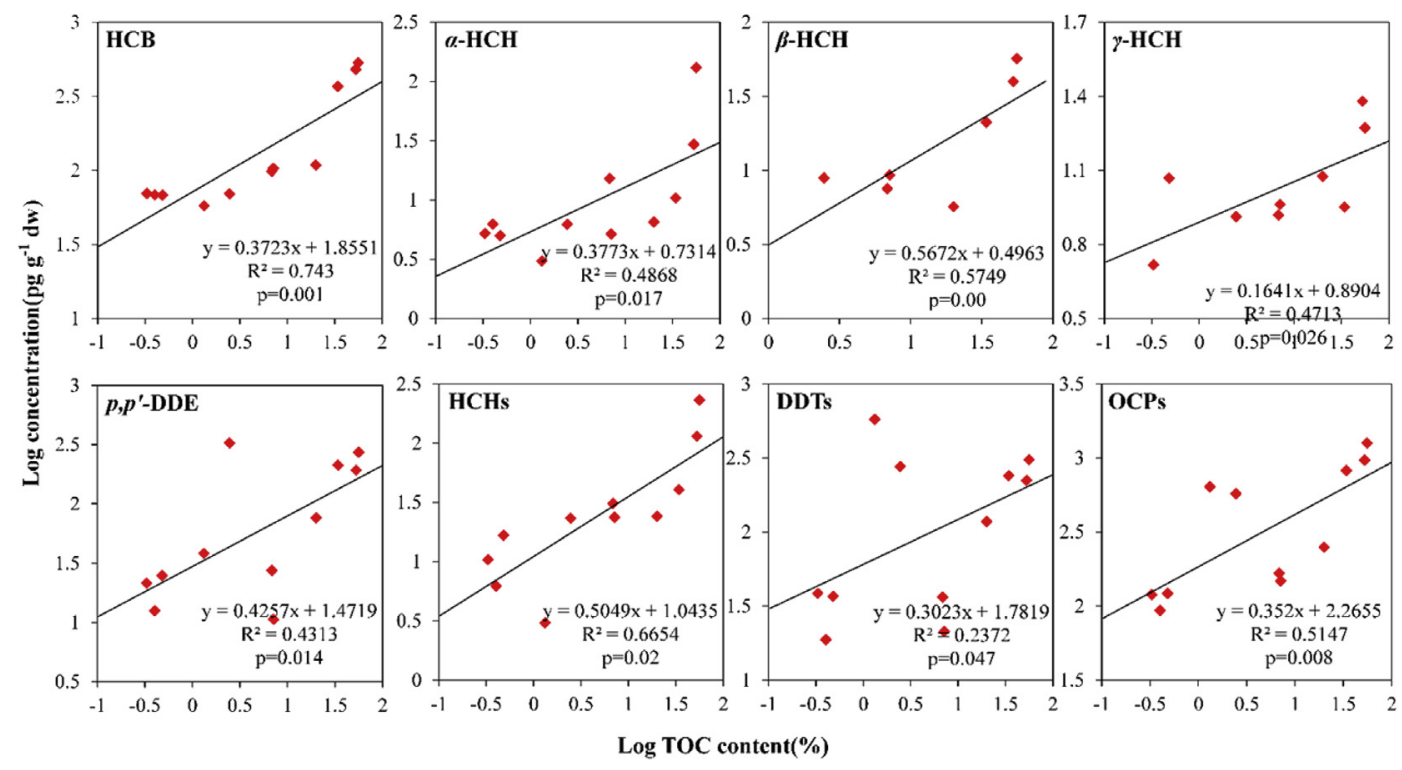

Fig. 4. Correlations between log OCPs concentrations ( $\mathrm{pg} \mathrm{g}^{-1} \mathrm{dw}$ ) vs. $\log$ TOC contents (\%) in soil and sediment samples. 


\section{Conclusions}

In this study, HRGC/HRMS technique was adopted for determination of twenty-three OCPs in various environmental matrices including soil, sediment, moss and lichen from west Antarctica. Based on these data, the levels, distributions and potential sources of OCPs were discussed. Concentrations of $\Sigma_{23} \mathrm{OCPs}$ were generally at quite low levels, of which $\mathrm{HCB}$, DDTs and $\mathrm{HCH}$ were dominant pollutants. CHLs, aldrin, dieldrin, endrin, and mirex were found at low frequencies, most of which were mainly detected in droppingamended soil. The ratios of $\alpha-\gamma-\mathrm{HCH}$ suggested that $\mathrm{HCHs}$ in Antarctica were influenced by the combined sources of "old" technical HCH and "recent" lindane. The $p, p^{\prime}$-DDE/p, $p^{\prime}$-DDT and TC/ $\mathrm{CC} / \mathrm{TN}$ ratios indicated an aged source of technical DDT and technical chlordane, respectively. Statistical significance of many OCPs concentrations vs. TOC contents in soil and sediment indicated the important effect of TOC on the distribution of OCPs in Polar Regions. Long-range atmospheric transport and local biotic activities were suspected to contribute to the pollution and spatial distribution of the contaminants in this pristine area.

\section{Acknowledgments}

This study was jointly funded by National Natural Science Foundation of China $(41276195,21477155,21321004)$, the Strategic Priority Research Program of the Chinese Academy of Sciences (XDB14010100), Young Scientists Fund of RCEES (RCEES-QN20130005F) and the State Oceanic Administration, China (2011GW02003).

\section{Appendix A. Supplementary data}

Supplementary data related to this article can be found at http:// dx.doi.org/10.1016/j.envpol.2015.06.025.

\section{References}

Ali, U., Syed, J.H., Malik, R.N., Katsoyiannis, A., Li, J., Zhang, G., Jones, K.C., 2014. Organochlorine pesticides (OCPs) in South Asian region: a review. Sci. Total. Environ. 476, 705-717.

ATSDR (Agency for Toxic Substances and Disease Registry), 2002a. Toxicological Profile for Aldrin and Dieldrin. US Department of Health and Human Services, Public Health Service, Atlanta, GA. Available at: http://www.atsdr.cdc.gov/ toxprofiles/tp1.pdf.

ATSDR (Agency for Toxic Substances and Disease Registry), 2002b. Toxicological Profile for DDT, DDE, and DDD. US Department of Health and Human Services, Public Health Service, Atlanta, GA. Available at: http://www.atsdr.cdc.gov/ toxprofiles/tp35.pdf.

ATSDR (Agency for Toxic Substances and Disease Registry), 2007. Toxicological Profile for Heptachlor and Heptachlor Epoxide. US Department of Health and Human Services, Public Health Service, Atlanta, GA. Available at: http://www. atsdr.cdc.gov/toxProfiles/tp12.pdf.

Bacci, E., Calamari, D., Gaggi, C., Fanelli, R., Focardi, S., Morosini, M., 1986. Chlorinated hydrocarbons in lichen and moss samples from the Antarctic Peninsula. Chemosphere 15, 747-754.

Baek, S.Y., Choi, S.D., Chang, Y.S., 2011. Three-year atmospheric monitoring of organochlorine pesticides and polychlorinated biphenyls in Polar Regions and the South Pacific. Environ. Sci. Technol. 45, 4475-4482.

Blais, J.M., Macdonald, R.W., Mackay, D., Webster, E., Harvey, C., Smol, J.P., 2007. Biologically mediated transport of contaminants to aquatic systems. Environ. Sci. Technol. 41, 1075-1084.

Borghini, F., Grimalt, J.O., Sanchez-Hernandez, J.C., Bargagli, R., 2005. Organochlorine pollutants in soils and mosses from Victoria Land (Antarctica). Chemosphere $58,271-278$

Breivik, K., Alcock, R., Li, Y.F., Bailey, R.E., Fiedler, H., Pacyna, J.M., 2004. Primary sources of selected POPs: regional and global scale emission inventories. Environ. Pollut. 128, 3-16.

Brubaker, W.W., Hites, R.A., 1998. OH reaction kinetics of gas-phase $\alpha$ - and $\gamma$-hexachlorocyclohexane and hexachlorobenzene. Environ. Sci. Technol. 32, $766-769$.

Cabrerizo, A., Dachs, J., Barceló, D., Jones, K.C., 2012. Influence of organic matter content and human activities on the occurrence of organic pollutants in Antarctic soils, lichens, grass, and mosses. Environ. Sci. Technol. 46, 1396-1405.
Chen, Z.J., Li, Y.M., Wang, P., Zhu, C.F., Gao, G.J., Xiao, K., Ren, D.W., Zhang, Q.H., 2014. The determination of organochlorine pesticides in Antarctic samples using high resolution gas chromatography/high resolution mass spectrometry (HRGC) HRMS). Environ. Chem. 33, 1655-1661 (in Chinese).

Cipro, C.V.Z., Yogui, G.T., Bustamante, P., Taniguchi, S., Sericano, J.L., Montone, R.C., 2011. Organic pollutants and their correlation with stable isotopes in vegetation from King George Island, Antarctica. Chemosphere 85, 393-398.

Connell, D.W., Miller, G.J., Mortimer, M.R., Shaw, G.R., Anderson, S.M., 1999. Persistent lipophilic contaminants and other chemical residues in the Southern Hemisphere. Crit. Rev. Env. Sci. Technol. 29, 47-82.

Evenset, A., Carroll, J., Christensen, G.N., Kallenborn, R., Gregor, D., Gabrielsen, G.W., 2007. Seabird guano is an efficient conveyer of persistent organic pollutants (POPs) to Arctic lake ecosystems. Environ. Sci. Technol. 41, 1173-1179.

Focardi, S., Gaggi, C., Chemello, G., Bacci, E., 1991. Organochlorine residues in moss and lichen samples from two Antarctic areas. Polar Rec. 27, 241-244.

Galbán-Malagón, C.J., Del Vento, S., Berrojalbiz, N., Ojeda, M.J., Dachs, J., 2013a. Polychlorinated biphenyls, hexachlorocyclohexanes and hexachlorobenzene in seawater and phytoplankton from the Southern Ocean (Weddell, South Scotia, and Bellingshausen Seas). Environ. Sci. Technol. 47, 5578-5587.

Galbán-Malagón, C., Cabrerizo, A., Caballero, G., Dachs, J., 2013b. Atmospheric occurrence and deposition of hexachlorobenzene and hexachlorocyclohexanes in the Southern Ocean and Antarctic Peninsula. Atmos. Environ. 80, 41-49.

Hitch, R.K., Day, H.R., 1992. Unusual persistence of DDT in some Western USA soils. B. Environ. Contam. Toxicol. 48, 259-264.

Iwata, H., Tanabe, S., Sakai, N., Tatsukawa, R., 1993. Distribution of persistent organochlorines in the oceanic air and surface seawater and the role of ocean on their global transport and fate. Environ. Sci. Technol. 27, 1080-1098.

Kang, J.H., Son, M.H., Hur, S.D., Hong, S., Motoyama, H., Fukui, K., Chang, Y.S., 2012. Deposition of organochlorine pesticides into the surface snow of East Antarctica. Sci. Total. Environ. 433, 290-295.

Kawano, M., Inoue, T., Wada, T., Hidaka, H., Tatsukawa, R., 1988. Bioconcentration and residue patterns of chlordane compounds in marine animals: invertebrates, fish, mammals, and seabirds. Environ. Sci. Technol. 22, 792-797.

Kim, J.H., Ahn, I.Y., Lee, K.S., Chung, H., Choi, H.G., 2007. Vegetation of Barton Peninsula in the neighbourhood of King Sejong Station (King George Island, maritime Antarctic). Polar Biol. 30, 903-916.

Kim, S.K., Oh, J.R., Shim, W.J., Lee, D.H., Yim, U.H., Hong, S.H., Shin, Y.B., Lee, D.S. 2002. Geographical distribution and accumulation features of organochlorine residues in bivalves from coastal areas of South Korea. Mar. Poll. Bull. 45, $268-279$.

Klánová, J., Matykiewiczová, N., Máčka, Z., Prošek, P., Láska, K., Klán, P., 2008. Persistent organic pollutants in soils and sediments from James Ross Island, Antarctica. Environ. Pollut. 152, 416-423.

Loganathan, B.G., Kannan, K., 1994. Global organochlorine contamination trends: an overview. Ambio 23, 187-191.

Meijer, S.N., Ockenden, W.A., Sweetman, A., Breivik, K., Grimalt, J.O., Jones, K.C., 2003. Global distribution and budget of PCBs and HCB in background surface soils: implications for sources and environmental processes. Environ. Sci. Technol. 37, 667-672.

Nam, J.J., Gustafsson, O., Kurt-Karakus, P., Breivik, K., Steinnes, E., Jones, K.C., 2008 Relationships between organic matter, black carbon and persistent organic pollutants in European background soils: implications for sources and environmental fate. Environ. Pollut. 156, 809-817.

Nash, S.B., 2011. Persistent organic pollutants in Antarctica: current and future research priorities. J. Environ. Monit. 13, 497-504.

Negoita, T.G., Covaci, A., Gheorghe, A., Schepens, P., 2003. Distribution of polychlorinated biphenyls (PCBs) and organochlorine pesticides in soils from the East Antarctic coast. J. Environ. Monit. 5, 281-286.

Pacyna, J.M., Oehme, M., 1988. Long-range transport of some organic compounds to the Norwegian Arctic. Atmos. Environ. 22, 243-257.

Pozo, K., Harner, T., Shoeib, M., Urrutia, R., Barra, R., Parra, O., Focardi, S., 2004. Passive-sampler derived air concentrations of persistent organic pollutants on a north-south transect in Chile. Environ. Sci. Technol. 38, 6529-6537.

Ribes, A., Grimalt, J.O., Torres García, C.J., Cuevas, E., 2002. Temperature and organic matter dependence of the distribution of organochlorine compounds in mountain soils from the Subtropical Atlantic (Teide, Tenerife Island). Environ. Sci. Technol. 36, 1879-1885.

Roosens, L., Van Den Brink, N., Riddle, M., Blust, R., Neels, H., Covaci, A., 2007. Penguin colonies as secondary sources of contamination with persistent organic pollutants. J. Environ. Monit. 9, 822-825.

Sladen, W.J.L., Menzie, C.M., Reichel, W.L., 1966. DDT residues in Adelie penguins and a Crabeater seal from Antarctica. Nature 210, 670-673.

Sovocool, G.W., Lewis, R.G., Harless, R.L., Wilson, N.K., Zehr, R.D., 1977. Analysis of technical chlordane by gas chromatography/mass spectrometry. Anal. Chem. 49, 734-740.

Sweetman, A.J., Valle, M.D., Prevedouros, K., Jones, K.C., 2005. The role of soil organic carbon in the global cycling of persistent organic pollutants (POPs): interpreting and modelling field data. Chemosphere 60, 959-972.

Tarcau, D., Cucu-Man, S., Boruvkova, J., Klanova, J., Covaci, A., 2013. Organochlorine pesticides in soil, moss and tree-bark from North-eastern Romania. Sci. Total. Environ. 456, 317-324.

Tatton, J.O., Ruzicka, J.H.A., 1967. Organochlorine pesticides in Antarctica. Nature $215,346-348$

UNEP (United Nations Environment Programme), 2001. Final Act of the Conference of Plenipotentiaries on the Stockholm Convention on Persistent Organic 
Pollutants, Stockholm, Sweden, 22 to 23 May 2001. Available at: http://www. pops.int/documents/meetings/dipcon/25june2001/conf4_finalact/en/finalactEnglish.PDF.

US EPA (US Environmental Protection Agency), 1998. Method 8270d: Semivolatile Organic Compounds by Gas Chromatography/mass Spectrometry GC/MS) Available at: http://www.epa.gov/wastes/hazard/testmethods/sw846/pdfs 8270d.pdf.

US EPA (US Environmental Protection Agency), 2007. Method 1699: Pesticides in Water, Soil, Sediment, Biosolids, and Tissue by HRGC/HRMS. Available at: http:/ water.epa.gov/scitech/methods/cwa/bioindicators/upload/2008_01_03 methods_method_1699.pdf.

Walker, K., Vallero, D.A., Lewis, R.G., 1999. Factors influencing the distribution of lindane and other hexachlorocyclohexanes in the environment. Environ. Sci. Technol. 33, 4373-4378.

Wang, P., Zhang, Q.H., Wang, T., Chen, W.H., Ren, D.W., Li, Y.M., Jiang, G.B., 2012. PCBs and PBDEs in environmental samples from King George Island and Ardley Island, Antarctica. RSC Adv. 2, 1350-1355.

Wang, X., Ren, N.Q., Qi, H., Ma, W.L., Li, Y.F., 2009. Levels, distributions, and source identification of organochlorine pesticides in the topsoils in Northeastern China. J. Environ. Sci. 21, 1386-1392.

Wania, F., MacKay, D., 1996. Peer reviewed: tracking the distribution of persistent organic pollutants. Environ. Sci. Technol. 30, 390-396.

Willett, K.L., Ulrich, E.M., Hites, R.A., 1998. Differential toxicity and environmenta fates of hexachlorocyclohexane isomers. Environ. Sci. Technol. 32, 2197-2207.

Wu, C.W., Zhang, A.P., Liu, W.P., 2013. Risks from sediments contaminated with organochlorine pesticides in Hangzhou, China. Chemosphere 90, 2341-2346.

Wu, Q.M., Wang, X., Zhou, Q.X., 2014. Biomonitoring persistent organic pollutants in the atmosphere with mosses: performance and application. Environ. Int. 66, 28-37.

Wu, W.Z., Xu, Y., Schramm, K.W., Kettrup, A., 1997. Study of sorption, biodegradation and isomerization of $\mathrm{HCH}$ in stimulated sediment/water system. Chemosphere 35, 1887-1894.

Yang, R.Q., Zhang, S.J., Li, A., Jiang, G.B., Jing, C.Y., 2013. Altitudinal and spatial signature of persistent organic pollutants in soil, lichen, conifer needles, and bark of the Southeast Tibetan Plateau: implications for sources and environmental cycling. Environ. Sci. Technol. 47, 12736-12743.

Zhang, H.S., Wang, Z.P., Lu, B., Zhu, C., Wu, G.H., Walter, V., 2007. Occurrence of organochlorine pollutants in the eggs and dropping-amended soil of Antarctic large animals and its ecological significance. Sci. China Ser. D 50, 1086-1096.

Zhang, L., Dickhut, R. DeMaster, D., Pohl, K., Lohmann, R., 2013. Organochlorine pollutants in Western Antarctic Peninsula sediments and benthic deposit feeders. Environ. Sci. Technol. 47, 5643-5651. 